\title{
Findings from Multipurpose IoT Solution Experimentations in Finnish SMEs: Common Expectations and Challenges
}

\author{
Mikko Vermanen \\ University of Turku \\ mikko.vermanen@utu.fi
}

\author{
Ville Harkke \\ University of Turku \\ ville.harkke@utu.fi
}

\begin{abstract}
The Finnish SMEs are showing increasing interest in modern digital solutions in hopes of streamlining their work processes. At the same time, the companies are struggling with resourcing issues and find it challenging to familiarize themselves with new solutions and how those could be applied in their business environment. To support the technical transition, we provided 10 Finnish SMEs with multipurpose IoT solutions, allowing them to conduct guided experimentations with relevant objectives. The business areas of the target companies varied widely from manufacturing to transportation and accommodation, as did their individual needs and expectations towards IoT. Based on this multifaceted background, we compared the companies' original expectations with the actualised experimentation outcomes, aiming at identifying commonly occurring challenges linked to multipurpose IoT solutions. As a result, an overview of the generalizable findings was gathered to offer further insight on how the multipurpose IoT devices could better serve the SMEs.
\end{abstract}

\section{Introduction}

The Internet of things is claimed to revolutionize the structures of the way business is conducted. [1][2][3] For the small- and medium-sized enterprises the promises of increased connectedness have been somewhat vague and the benefits of IOT are not fully understood. [4] There are various ways of increasing the knowledge and understanding of SME representatives about the benefits of this technology, ranging from presenting real-life success stories to concrete solution experimentations. In order to scrutinize the process of knowledge acquisition and integrating the IOT-based knowledge into the business processes of Finnish SMEs, we conducted a series of pilot experiments where the SMEs were provided with multipurpose IOT sensor solutions with accompanying software interfaces.
Our study showed that some of the most desirable characteristics of multipurpose IoT solutions were, from the SMEs' standpoint, their perceived simplicity and straightforward installation, accompanied by affordability [5]. These features were believed to reduce the need for internal technical expertise required for successful ICT (information and communications technology) adoption [6], allowing the less technology-oriented SMEs to harness the expected benefits [7] without a need for additional training or external consulting services. However, our experiments and the target companies' past experiences demonstrated that the deployment projects lacking analytical and tailored approach do include significant risks in terms of reaching the company-specific benefit potential, in worst cases leading to the abandonment of the solution.

While it was already acknowledged that the generic and low-cost packaged solutions [8] may not be optimal choices for permanent use in most organizations, the experimentations were carried out simulating real-life implementation projects in order to draw substantiated conclusions on how the tested solutions would manage to fulfill the SMEs' initial expectations. By fitting the IoT solutions into the actual work processes of the target companies, we were able to observe not only the IoT solutions' general performance, but also the actual outcomes in real business environments. By combining the expectations with the achieved results, we managed to identify the most common challenges and shortcomings related to the multipurpose IoT solutions. Thus, the research questions were as follows:

-What generalizable conflicts can be found between the expectations towards multipurpose IoT solutions and the realised outcomes in Finnish SMEs?

-Based on the identified conflicts, what are the most crucial development areas related to the multipurpose IoT solutions when considering their ability to fulfill the requirements of Finnish SMEs? 
-Could a list of the characteristics of a sufficient multipurpose sensoring IOT system for experimenting and piloting purposes be constructed?

-How did the experimentations affect the target company representatives' attitudes and intentions towards IoT solutions?

The factors affecting any information system adoption and success have been under study since the emergence of information technologies in business. Different explanation models have been presented and validated. (See Venkatesh \& Davis [9], DeLone and Mclean [10] and Seddon, P. B. [11]) In this work we are not using any of the general models but are concentrating on the details specific for IOT implementations for SMEs regardless where those details would place in the models.

\section{Materials and methods}

In this paper we utilise the interview and survey data gathered from the previously conducted IoT experimentation project. The business areas of the chosen target companies varied from industrial sector to transportation and accommodation, as did their needs and expectations towards IoT. What was common among the cases was that the presented challenges and development ideas had to be possible to answer with sensor technology. To collect and observe the sensor data, each target company was provided with a multipurpose IoT device and a web-based user interface. The interface was a simulation of the service provider's default software, the only major difference being the restrictions in configuration features, which was a safety measure aiming to prevent user-induced distractions.

In order to create a rich picture of the test cases a multimodal data gathering took place. The participants answered two online surveys, first one to establish a pretest level of IOT knowledge and attitude and a second one after the test period, measuring changes in attitude and knowledge and asking for the major learning experiences during the test period. In addition to that, the participants were subject to weekly semi-structured interviews and up to three observation/guidance sessions by the field researchers. In order to strengthen and validate the observational and self-reported data, all sensor data from the pilot systems was collected to our server and cross- checked against the impressions from other data sources.

These data were then analysed by seeking common denominators, explanations and causal connections. The pursued goal was to find common differences between the SMEs' expectations and the realised outcomes of the experiments. Finally, the results were combined into a group of generalizable findings, whose identification was aimed to provide further insight on the SMEs' requirements towards sensor-based IoT solutions. The analysis was conducted by implementing the grounded theory methods as described by Corbin et al. [12] Given the exploratory nature of this study the methodology chosen was deemed to be sufficient for recognizing the previously uncharted factors affecting the IOT usage of SMEs.

Considering the implementation of a new technical solution, it is relevant to investigate the relationship between the end-users and the said solution. For this purpose, the Technology Acceptance Model (TAM) [13] is the most proven and well-researched tool. During its lifetime, the TAM has seen several evolutionary steps, perhaps most importantly the one introduced by Venkatesh \& Davis, also know as TAM2. [14] TAM has already been utilised in past IoT research and even accommodated to better suit this research area. An example of such effort is present in the article of Gao and Bai [15], where the writers introduce a consumercentric IoT acceptance model, extending the original TAM with three additional variables: social influence, perceived enjoyment and perceived behavioral control. However, as this article concentrates mainly on the relationship and suitability factors between the target organizations and the utilised IoT solutions, the user aspect is not highlighted. As an additional remark, we are already preparing a separate article addressing these topics.

\section{Deployed IoT solution}

A large variety of different IoT solutions is currently available for commercial use, and according to some of our target companies, the multiplicity of available options can be overwhelming, especially from a less technology-oriented SME's standpoint. To bring our contribution to this issue, we contacted 11 Finnish IoT service providers, aiming to find a solution which could serve a group of SMEs from different business areas. A majority of the contacted service providers were specialized in providing rather specific or tailor-made solutions for accurately defined sensoring purposes, often with large budgets. These solutions varied from observing environmental variables or tracking logistical functions in large industrial complexes with hundreds of sensor units to focusing strictly on vehicles by monitoring their location, speed and fuel consumption.

To fulfill the purpose of this research, we had to find an alternative which could serve an audience with more heterogeneous needs, resulting in purchasing multipurpose IoT solutions with multiple built-in sensors. The purchased multipurpose IoT solution, acquired from a Finnish company specialized in IoT technology, was built around the idea of including a 
variety of sensors inside a single, affordable device. The available sensors were acceleration, air pressure, humidity, impact, luminance, gps-based location, orientation, speed and temperature.

Considering the technical limitations, it was readily acknowledged that some accuracy issues were likely to occur, partly related to the low production costs and the small size of this device, and hence the results should be considered as approximations, as recommended also by the service provider. However, compared to the other options available at that time, the chosen IoT solution provided a better basis for conducting diverse experimentations without a need for hardware additions or customizations. Regarding the connectivity, the devices had individual SIM cards and used a $2 \mathrm{~g}$ connection by default, but could also be connected to a wifi network. The devices also included built-in batteries to allow usage in locations where external power sources were not available.

The IoT solution was delivered with a webbased user interface, which enabled the observation of real-time sensor values and a map for tracking the device location in case the gps-based location sensor was activated. The sensor data was by default delivered through the service provider's cloud service using a wifi or alternatively $2 \mathrm{~g}$ connection, depending on whether a local wifi network was available. In addition to the realtime values, the last 60 sensor values were displayed in text format. However, it is important to acknowledge that in this research we created a simulated version of the default user interface, which enabled us to channel the data via our own database server and to restrict the configuration options of the user interface to avoid userinduced experimentation interruptions. Thus, we were able to store all the collected data for further internal inspection and future research purposes.

\section{Experimentation settings and results}

\subsection{Experimentations}

Below we will introduce the background information of the participating target companies and the initial purpose of each IoT experimentation (Table 1). We will then describe the target companies' expectations towards the IoT solutions and compare them with the realised results (Table 2). Finally, the gathered findings are assembled into a set of generalizable challenge areas commonly present in our experimentations.
Table 1. Target company backgrounds, experimentation purposes and applied sensors

\begin{tabular}{|c|c|c|c|c|}
\hline ID & $\begin{array}{l}\text { Business } \\
\text { area }\end{array}$ & Size & Purpose & Sensors \\
\hline 1 & Industrial & $<10$ & $\begin{array}{l}\text { Heat storage } \\
\text { space air } \\
\text { condition } \\
\text { surveillance to } \\
\text { identify possible } \\
\text { heat leakages }\end{array}$ & $\begin{array}{l}\text { Air pressure } \\
\text { Humidity } \\
\text { Temperature }\end{array}$ \\
\hline 2 & Industrial & $<250$ & $\begin{array}{l}\text { Server room air } \\
\text { condition } \\
\text { surveillance to } \\
\text { enhance the } \\
\text { reaction time in } \\
\text { emergency } \\
\text { situations }\end{array}$ & $\begin{array}{l}\text { Air pressure } \\
\text { Humidity } \\
\text { Temperature }\end{array}$ \\
\hline 3 & Industrial & $<10$ & $\begin{array}{l}\text { Verification of } \\
\text { underpressure } \\
\text { inside a } \\
\text { renovation room } \\
\text { to ensure optimal } \\
\text { working } \\
\text { conditions }\end{array}$ & $\begin{array}{l}\text { Air pressure } \\
\text { Temperature }\end{array}$ \\
\hline 4 & Industrial & $<50$ & $\begin{array}{l}\text { Material cutting } \\
\text { device usage } \\
\text { surveillance to } \\
\text { increase work } \\
\text { efficiency and } \\
\text { avoid downtime }\end{array}$ & $\begin{array}{l}\text { Impact } \\
\text { Speed } \\
\text { Orientation }\end{array}$ \\
\hline 5 & Industrial & $<10$ & $\begin{array}{l}\text { Air condition } \\
\text { surveillance in } \\
\text { various work and } \\
\text { industrial spaces } \\
\text { to ensure optimal } \\
\text { customer } \\
\text { satisfaction }\end{array}$ & $\begin{array}{l}\text { Air pressure } \\
\text { Humidity } \\
\text { Temperature }\end{array}$ \\
\hline 6 & Hotel & $<10$ & $\begin{array}{l}\text { Hotel room air } \\
\text { condition } \\
\text { surveillance to } \\
\text { optimise energy } \\
\text { consumption and } \\
\text { customer } \\
\text { satisfaction }\end{array}$ & $\begin{array}{l}\text { Air pressure } \\
\text { Humidity } \\
\text { Temperature }\end{array}$ \\
\hline 7 & Hotel & $<10$ & $\begin{array}{l}\text { Ball room air } \\
\text { condition } \\
\text { surveillance to } \\
\text { optimize the }\end{array}$ & $\begin{array}{l}\text { Air pressure } \\
\text { Humidity } \\
\text { Temperature }\end{array}$ \\
\hline
\end{tabular}




\begin{tabular}{|l|l|l|l|l|}
\hline & & & $\begin{array}{l}\text { heating and air } \\
\text { conditioning in } \\
\text { different events }\end{array}$ & \\
\hline 8 & Logistics & $<10$ & $\begin{array}{l}\text { Storage room air } \\
\text { condition } \\
\text { surveillance to } \\
\text { ensure product } \\
\text { safety and to } \\
\text { investigate the } \\
\text { impacts of the } \\
\text { outside air }\end{array}$ & $\begin{array}{l}\text { Humidity } \\
\text { Temperature } \\
\text { Orientation }\end{array}$ \\
\hline 9 & Car rental & $<10$ & $\begin{array}{l}\text { Geofence-based } \\
\text { rental car location } \\
\text { surveillance to } \\
\text { receive real-time } \\
\text { information of the } \\
\text { returned vehicles }\end{array}$ & Location \\
\hline 10 & Plant care & $<10$ & $\begin{array}{l}\text { Plant service } \\
\text { interval } \\
\text { optimization } \\
\text { based on soil } \\
\text { condition change } \\
\text { interval } \\
\text { observation }\end{array}$ & Humidity \\
Temperature & \\
\hline
\end{tabular}

Table 2. Initial expectations and key findings

\begin{tabular}{|c|c|c|}
\hline ID & Expectations & Findings \\
\hline 1 & $\begin{array}{l}\text { The target } \\
\text { company's goal } \\
\text { was to remotely } \\
\text { monitor the } \\
\text { conditions in a } \\
\text { heat storage space } \\
\text { and to receive } \\
\text { notifications if the } \\
\text { set threshold } \\
\text { values had been } \\
\text { exceeded. As a } \\
\text { safety measure } \\
\text { rather than a part } \\
\text { the company's } \\
\text { core } \\
\text { functionalities, the } \\
\text { idea was to } \\
\text { automate the } \\
\text { previously manual } \\
\text { surveillance } \\
\text { activities. }\end{array}$ & $\begin{array}{l}\text { Based on the post-experiment } \\
\text { interview, the target company } \\
\text { claimed to have gained a } \\
\text { somewhat better understanding } \\
\text { of the possibilities of IoT } \\
\text { technology and believed it to } \\
\text { possess a significant benefit } \\
\text { potential in their specific } \\
\text { business area, as long as the } \\
\text { quality of the product fulfills } \\
\text { the requirements of } \\
\text { professional use. Within this } \\
\text { experiment, the collected data } \\
\text { wasn't found accurate enough } \\
\text { to be relied on due to several } \\
\text { technical issues. Firstly, the } \\
\text { temperature data was } \\
\text { impossible to use according to } \\
\text { the target company, as } \\
\text { charging the device would } \\
\text { temporarily rise the measured }\end{array}$ \\
\hline
\end{tabular}

\begin{tabular}{|c|c|c|}
\hline & $\begin{array}{l}\text { Simultaneously, } \\
\text { the target } \\
\text { company wanted } \\
\text { to learn and adapt } \\
\text { to a new digital } \\
\text { solution through } \\
\text { concrete } \\
\text { experience, based } \\
\text { on which they } \\
\text { believed to } \\
\text { discover more } \\
\text { developed means } \\
\text { to utilise IoT. }\end{array}$ & $\begin{array}{l}\text { values significantly compared } \\
\text { to battery powered use. } \\
\text { Secondly, the limited battery } \\
\text { life and constant connectivity } \\
\text { issues caused too many } \\
\text { interruptions in data collection, } \\
\text { which could lead to dismissed } \\
\text { risk situations. } \\
\text { That said, although the } \\
\text { wireless sensoring solutions } \\
\text { are in the interests of the target } \\
\text { company in the future, the } \\
\text { purchased solution should } \\
\text { represent a dramatically higher } \\
\text { maturity level in terms of } \\
\text { reliability, accuracy and ease } \\
\text { of use. As a whole, the target } \\
\text { company stated that the } \\
\text { experiment encouraged them } \\
\text { to start using IoT and that it } \\
\text { will actually become an } \\
\text { industry standard in SMEs in } \\
\text { the near future and thus a } \\
\text { mandatory step to ensure } \\
\text { competitiveness. }\end{array}$ \\
\hline & $\begin{array}{l}\text { The idea of the } \\
\text { experimentation } \\
\text { was to test a } \\
\text { solution that } \\
\text { would eliminate } \\
\text { the need for } \\
\text { manual machine } \\
\text { room surveillance } \\
\text { and to receive } \\
\text { exception } \\
\text { notifications when } \\
\text { set value } \\
\text { thresholds had } \\
\text { been exceeded. }\end{array}$ & $\begin{array}{l}\text { The accuracy of the tested } \\
\text { device wasn't found sufficient, } \\
\text { mainly due to the problems } \\
\text { related to temperature } \\
\text { measurement. Most of these } \\
\text { problems were caused by the } \\
\text { rise of temperature caused by } \\
\text { battery charging, which } \\
\text { couldn't be prevented due to } \\
\text { the limited battery life when } \\
\text { unplugged from a power } \\
\text { output. Additionally, several } \\
\text { connectivity issues were faced } \\
\text { during the experimentation } \\
\text { caused not only by depleted } \\
\text { battery, but also } \\
\text { malfunctioning network } \\
\text { features. That said, the target } \\
\text { company's opinion was that on } \\
\text { the fundamental level the } \\
\text { tested device would suit their } \\
\text { needs and could reach the } \\
\text { required quality level with } \\
\text { relatively simple hardware } \\
\text { upgrades from the service } \\
\text { provider. }\end{array}$ \\
\hline
\end{tabular}




\begin{tabular}{|c|c|c|}
\hline 3 & $\begin{array}{l}\text { The target } \\
\text { company needed } \\
\text { to verify that } \\
\text { underpressure has } \\
\text { been maintained } \\
\text { in a renovation } \\
\text { space throughout } \\
\text { the working } \\
\text { period. If the } \\
\text { measurement was } \\
\text { successful, the } \\
\text { company would } \\
\text { be interested in } \\
\text { using a similar } \\
\text { solution in other } \\
\text { renovation spaces } \\
\text { as well to be able } \\
\text { to prove that the } \\
\text { work conditions } \\
\text { have been } \\
\text { maintained as } \\
\text { agreed. }\end{array}$ & $\begin{array}{l}\text { The target company was able } \\
\text { to observe the real-time air } \\
\text { pressure as intended. However, } \\
\text { due to the lack of extensive } \\
\text { historical data availability, the } \\
\text { collected values had to be } \\
\text { logged manually. This was } \\
\text { seen as a critical issue, } \\
\text { eliminating most of the } \\
\text { expected process streamlining } \\
\text { expected from IoT } \\
\text { deployment. Additionally, the } \\
\text { battery, connectivity and } \\
\text { accuracy issues caused too } \\
\text { many gaps in collected values. } \\
\text { Referring to the target } \\
\text { company's statements, a } \\
\text { similar product with a higher } \\
\text { maturity level regarding both } \\
\text { the software and hardware } \\
\text { would make a significant } \\
\text { difference in their attitude, } \\
\text { likely leading to permanent } \\
\text { use. Overall, the target } \\
\text { company stated that the } \\
\text { experiment raised their } \\
\text { understanding on IoT's } \\
\text { applicability in their specific } \\
\text { business. However, achieving } \\
\text { the expected benefits with the } \\
\text { tested solution would have } \\
\text { been too cumbersome to } \\
\text { justify the investment. }\end{array}$ \\
\hline 4 & $\begin{array}{l}\text { The target } \\
\text { company wanted } \\
\text { to identify the } \\
\text { inactivity periods } \\
\text { by monitoring the } \\
\text { cutting machine's } \\
\text { usage intensity, } \\
\text { and to optimize } \\
\text { the machine } \\
\text { workload based on } \\
\text { this information } \\
\text { by adding tasks in } \\
\text { between the } \\
\text { activity periods. } \\
\text { Their further plan } \\
\text { was to utilize the } \\
\text { IoT solution's alert } \\
\text { functionality to } \\
\text { eliminate the need } \\
\text { for manual } \\
\text { monitoring, once }\end{array}$ & $\begin{array}{l}\text { The accuracy of the utilized } \\
\text { sensors failed to meet the } \\
\text { customer's expectations. } \\
\text { Regardless of the measuring } \\
\text { interval, the IoT device wrote } \\
\text { several duplicate values in a } \\
\text { row, failing to identify the } \\
\text { smaller movements, leading to } \\
\text { the false interpretation that the } \\
\text { machine was inactive. } \\
\text { Although the software } \\
\text { interface included an alert } \\
\text { functionality, its activation } \\
\text { wasn't seen useful until the } \\
\text { sensor calibration had been } \\
\text { ensured. As this couldn't be } \\
\text { done successfully during the } \\
\text { experimentation period, the } \\
\text { functionality was not activated. } \\
\text { Regardless of the fact that the } \\
\text { tested device received bad }\end{array}$ \\
\hline
\end{tabular}

\begin{tabular}{|c|c|c|}
\hline & $\begin{array}{l}\text { its functioning had } \\
\text { been proven. }\end{array}$ & $\begin{array}{l}\text { feedback, the target company } \\
\text { expressed that the } \\
\text { experimentation managed to } \\
\text { enhance their understanding } \\
\text { regarding the potential of IoT } \\
\text { specifically in their own } \\
\text { business. Furthermore, the } \\
\text { company representative stated } \\
\text { that due to the grown IoT } \\
\text { awareness they will likely } \\
\text { invest in a suitable IoT } \\
\text { solution in the near future. }\end{array}$ \\
\hline 5 & $\begin{array}{l}\text { The main } \\
\text { expectation of the } \\
\text { target company } \\
\text { was to automate } \\
\text { their building } \\
\text { condition } \\
\text { surveillance } \\
\text { functions. This } \\
\text { would allow them } \\
\text { to streamline work } \\
\text { processes and to } \\
\text { provide better } \\
\text { customer service } \\
\text { through faster } \\
\text { reaction times and } \\
\text { enhanced } \\
\text { capability to find } \\
\text { the underlying } \\
\text { root-causes. }\end{array}$ & $\begin{array}{l}\text { The target company decided to } \\
\text { apply an open approach } \\
\text { towards the experiment, as } \\
\text { they didn't want to limit their } \\
\text { use of IoT into one specific } \\
\text { function or customer. This } \\
\text { approach produced several } \\
\text { sensoring ideas, ranging from } \\
\text { temperature surveillance in a } \\
\text { manufacturing space to air } \\
\text { pressure observation in a } \\
\text { bakery. Although the } \\
\text { commonly faced accuracy } \\
\text { issues were present in this case } \\
\text { as well, the target company } \\
\text { claimed that even the } \\
\text { approximate sensor values } \\
\text { provided useful information, } \\
\text { primarily supporting the } \\
\text { verification of the expected } \\
\text { root causes behind possible air } \\
\text { condition issues reported by } \\
\text { their customers. The } \\
\text { experiment was seen to } \\
\text { significantly enhance the target } \\
\text { company's understanding and } \\
\text { attitudes towards IoT, } \\
\text { encouraging them to go } \\
\text { forward with the IoT } \\
\text { investment plans. }\end{array}$ \\
\hline
\end{tabular}




\begin{tabular}{|c|c|c|}
\hline 6 & $\begin{array}{l}\text { The long term } \\
\text { goal of the } \\
\text { company was to } \\
\text { integrate the IoT } \\
\text { solution as a tool } \\
\text { for hotel room air } \\
\text { condition } \\
\text { automatization } \\
\text { through adjusting } \\
\text { the conditions } \\
\text { based on the } \\
\text { collected sensor } \\
\text { values. This was } \\
\text { expected help the } \\
\text { company to } \\
\text { streamline their } \\
\text { energy } \\
\text { consumption } \\
\text { while ensuring } \\
\text { customer } \\
\text { satisfaction. } \\
\text { During the } \\
\text { experiment, the } \\
\text { target company } \\
\text { wanted to ensure } \\
\text { that the gathered } \\
\text { data could serve } \\
\text { this purpose. }\end{array}$ & $\begin{array}{l}\text { The use of IoT turned out to be } \\
\text { more cumbersome than } \\
\text { expected. To fulfil the } \\
\text { mentioned expectations, the } \\
\text { solution should be able to } \\
\text { deliver trustworthy } \\
\text { information without } \\
\text { continuous manual effort } \\
\text { caused by calibration and } \\
\text { battery issues. All hotel rooms } \\
\text { could still be successfully } \\
\text { observed during the } \\
\text { experimentation, and the data } \\
\text { did provide useful information } \\
\text { especially regarding the } \\
\text { differences between the rooms. } \\
\text { That said, the target } \\
\text { company's knowledge about } \\
\text { IoT's applicability in their own } \\
\text { business was considerably } \\
\text { enhanced, as did their overall } \\
\text { attitude towards IoT solutions. } \\
\text { As a conclusion, the company } \\
\text { representative stated that they } \\
\text { would be interested in } \\
\text { purchasing IoT solutions in the } \\
\text { future, given that the technical } \\
\text { shortcomings will be reduced } \\
\text { by better reliability and } \\
\text { usability. }\end{array}$ \\
\hline 7 & $\begin{array}{l}\text { The target } \\
\text { company needed } \\
\text { an IoT solution to } \\
\text { deliver air } \\
\text { condition data } \\
\text { measured from } \\
\text { their hotel ball } \\
\text { room, based on } \\
\text { which they could } \\
\text { adjust the } \\
\text { temperature and } \\
\text { air conditioning to } \\
\text { better } \\
\text { accommodate the } \\
\text { needs of their } \\
\text { event visitors. } \\
\text { Although they had } \\
\text { already observed } \\
\text { the temperature } \\
\text { manually, IoT was } \\
\text { seen as an } \\
\text { interesting } \\
\text { addition that could } \\
\text { help the target }\end{array}$ & $\begin{array}{l}\text { The target company } \\
\text { representative stated that the } \\
\text { solution managed to produce } \\
\text { beneficial information } \\
\text { regarding the air conditions, } \\
\text { especially in terms of } \\
\text { measurement trends drawn } \\
\text { from the historical data. This } \\
\text { helped the company to better } \\
\text { predict the heating and air } \\
\text { conditioning requirements in } \\
\text { their future events and was } \\
\text { believed to enhance the } \\
\text { customer satisfaction. Their } \\
\text { only complaint was related to } \\
\text { the inaccuracy of the } \\
\text { temperature sensor, which } \\
\text { wasn't however seen as a } \\
\text { critical issue, as their main } \\
\text { goal was to maintain the } \\
\text { relative conditions. As for their } \\
\text { attitude towards IoT and the } \\
\text { intentions to implement similar } \\
\text { solutions, both were changed }\end{array}$ \\
\hline
\end{tabular}

\begin{tabular}{|c|c|c|}
\hline & $\begin{array}{l}\text { company to } \\
\text { reduce manual } \\
\text { effort and to draw } \\
\text { long-term } \\
\text { conclusions. }\end{array}$ & $\begin{array}{l}\text { to a positive direction after the } \\
\text { experimentation. }\end{array}$ \\
\hline 8 & $\begin{array}{l}\text { The target } \\
\text { company needed } \\
\text { to ensure that the } \\
\text { air conditions in } \\
\text { their storage } \\
\text { spaces allowed the } \\
\text { best possible } \\
\text { shelf-life for the } \\
\text { stored products. } \\
\text { Additionally, the } \\
\text { company wanted } \\
\text { to observe the how } \\
\text { loading dock door } \\
\text { position would } \\
\text { affect the } \\
\text { surrounding } \\
\text { temperature and to } \\
\text { take action if the } \\
\text { outdoor } \\
\text { temperature could } \\
\text { potentially } \\
\text { endanger the } \\
\text { products stored } \\
\text { nearby. }\end{array}$ & $\begin{array}{l}\text { Connectivity issues were faced } \\
\text { frequently during the } \\
\text { experimentation, likely due to } \\
\text { the weak mobile network } \\
\text { signal. Additionally, like in } \\
\text { most other cases, the } \\
\text { temperature needed to be } \\
\text { observed as an approximation } \\
\text { as the devices needed to be } \\
\text { attached to a power source. } \\
\text { Another challenge was the fact } \\
\text { that the devices weren't } \\
\text { designed to cover as large } \\
\text { spaces as the storage. Because } \\
\text { of this, the values would vary } \\
\text { drastically between different } \\
\text { locations inside within the } \\
\text { same physical space and hence } \\
\text { should be collected by placing } \\
\text { the device in multiple places } \\
\text { during a measurement period. } \\
\text { Although several issues were } \\
\text { faced, the target company } \\
\text { claimed to be interested in } \\
\text { purchasing similar, yet more } \\
\text { reliable, IoT in the future to } \\
\text { help monitoring the storage } \\
\text { space conditions. }\end{array}$ \\
\hline 9 & $\begin{array}{l}\text { The target } \\
\text { company wanted } \\
\text { to test an IoT } \\
\text { device with a } \\
\text { geofence feature, } \\
\text { which they could } \\
\text { in the future } \\
\text { implement into all } \\
\text { of their rental cars. } \\
\text { According to the } \\
\text { target company, } \\
\text { this would }\end{array}$ & $\begin{array}{l}\text { From the functional } \\
\text { perspective, the target } \\
\text { company was satisfied with the } \\
\text { experiment and stated that the } \\
\text { device would be suitable for } \\
\text { long-term use. The information } \\
\text { about the tested car's arrival } \\
\text { was delivered promptly and no } \\
\text { significant issues were found } \\
\text { after the geo-fence range had } \\
\text { been configured. The target } \\
\text { company had already }\end{array}$ \\
\hline
\end{tabular}




\begin{tabular}{|c|c|c|}
\hline & $\begin{array}{l}\text { enhance the } \\
\text { service level } \\
\text { significantly, as } \\
\text { they would be } \\
\text { instantly aware of } \\
\text { the cars' arrival, } \\
\text { thus being able to } \\
\text { reduce inactivity } \\
\text { periods. }\end{array}$ & $\begin{array}{l}\text { unsuccessfully tested a similar } \\
\text { IoT solution before this } \\
\text { experiment, and claimed that } \\
\text { the new solution had a } \\
\text { significant positive impact on } \\
\text { their attitude towards IoT. } \\
\text { However, the price of the } \\
\text { device was considered too high } \\
\text { to allow a full-scale } \\
\text { implementation, as a full-scale } \\
\text { implementation would cover } \\
\text { more than } 100 \text { rental vehicles. } \\
\text { Hence, a product with a more } \\
\text { limited feature set would likely } \\
\text { reduce the expenses. }\end{array}$ \\
\hline 10 & $\begin{array}{l}\text { The target } \\
\text { company wanted } \\
\text { to streamline their } \\
\text { work processes by } \\
\text { replacing the } \\
\text { manual plant } \\
\text { status verification, } \\
\text { described by the } \\
\text { company } \\
\text { representative as } \\
\text { cumbersome, with } \\
\text { a remotely } \\
\text { readable IoT } \\
\text { solution. This goal } \\
\text { was planned to be } \\
\text { reached by first } \\
\text { identifying the } \\
\text { optimal service } \\
\text { intervals based on } \\
\text { the collected } \\
\text { humidity values, } \\
\text { and after that, } \\
\text { continuing remote }\end{array}$ & $\begin{array}{l}\text { Although IoT was believed to } \\
\text { possess significant benefit } \\
\text { potential in their business area, } \\
\text { the target company was not } \\
\text { able to fulfill their original } \\
\text { goal with the tested solution } \\
\text { due to both software and } \\
\text { hardware issues. As the default } \\
\text { interface stored and displayed } \\
\text { only the last } 50 \text { measurement } \\
\text { entries and didn't provide a } \\
\text { built-in visualization of the } \\
\text { historical values, the target } \\
\text { company couldn't efficiently } \\
\text { observe the long-term status } \\
\text { development independently. } \\
\text { The research team provided } \\
\text { the target company with } \\
\text { manually created } \\
\text { visualizations of the collected } \\
\text { values, which they perceived } \\
\text { as a useful feature that should }\end{array}$ \\
\hline
\end{tabular}

\subsection{Main findings}

Concluded from all target company feedback both verbal and written form, the differences between the expectations and concrete outcomes described below were especially pronounced. As a whole, the findings seem to match well with the challenge areas introduced by Williams [1], such as power management, scalability, usability, standardization and survivability. The findings can be categorized as follows.

\begin{tabular}{|c|c|}
\hline $\begin{array}{l}\text { monitoring to find } \\
\text { unexpected } \\
\text { discrepancies. The } \\
\text { importance of the } \\
\text { temperature } \\
\text { information was } \\
\text { secondary to the } \\
\text { target company, } \\
\text { but was used to } \\
\text { find possible } \\
\text { correlations. }\end{array}$ & $\begin{array}{l}\text { be readily available in the } \\
\text { solution. } \\
\text { From the hardware } \\
\text { perspective, it turned out that } \\
\text { the sensor values were highly } \\
\text { inaccurate based on the } \\
\text { comparison with manually } \\
\text { observed status. The reason } \\
\text { behind this was interpreted to } \\
\text { be partly caused by sub- } \\
\text { optimal placement of the } \\
\text { sensor; the device could not be } \\
\text { placed beneath the soil due to } \\
\text { its limited water resistance. } \\
\text { The device was also found to } \\
\text { be prone to reacting } \\
\text { dramatically on external } \\
\text { factors, such as minor water } \\
\text { spills and sunlight, causing } \\
\text { seemingly random value } \\
\text { spikes. Additionally, the } \\
\text { device recovered from these } \\
\text { changes slowly, invalidating } \\
\text { the results gathered during the } \\
\text { next several hours. However, } \\
\text { the results gathered in stable } \\
\text { conditions managed to show } \\
\text { some logical intervals, from } \\
\text { which the target company } \\
\text { claimed to have received } \\
\text { usable information, yet } \\
\text { couldn't fully trust the results } \\
\text { due to the previously } \\
\text { mentioned technical } \\
\text { shortcomings, whose absence } \\
\text { couldn't be verified. }\end{array}$ \\
\hline
\end{tabular}

\subsection{Technical findings}

Accuracy: In majority of cases the sensor accuracy was considered insufficient. Most often the perceived inaccuracy wasn't dramatic, but still crossed the line where the target company considered the benefits to be lost. In some of the more unique experiments, such as tracking the movement of the industrial cutting machine, the IoT solution couldn't provide almost any usable information.

Reliability: Battery life and connectivity issues were faced frequently throughout the experiments. The 
battery life challenges could be eliminated by using external power sources, however in those cases at least the temperature values were altered significantly, and thus could not be relied upon.

Usability: Most companies mentioned that the usability of the UI and the visualisation of sensor data would affect their willingness to purchase an IoT solution. The missing historical data in the out-of-the-box UI was also found as a critical shortcoming, as it would practically eliminate the ability to make decisions based on longterm observations. As a whole, there was a clear demand for a further productized solution.

Integration: A common, yet not as critical, challenge is the fact that the IoT solution used in these experiments was a standalone product. As a result, it would add the number of work tools which can already be too high from the employee's perspective, in worst case leading to reduced performance. Thus, it was often stated that by integrating the IoT solution as part of the target companies' existing software tools, they could not only reduce the workload of the individual, but also to combine the IoT data with other existing information more fluently.

\subsection{Organizational findings}

Resourcing: Composed from all previously mentioned factors, the need for resourcing surprised some the companies. Although many believed this to be a temporary condition connected to the implementation phase, most expected a more effortless and automated implementation process.

Expenses: Finally, as the needs of the target companies were often relatively simple, there was a common expectation that even a low-cost solution could provide financial value quickly and with little effort. Although understandable, this expectation was not usually met, as each case revealed at least some requirements for further investments in form of either money or personal resourcing to reach the actual benefits. That said, even in the most trivial cases it was found that the purchase decision should be well prepared and requires at least temporary redirection of personal effort. Due to these challenges, the companies were less certain about the lucrativity of the investment, and expressed a need for further proof of benefits, for example in form of preexisting success stories.

Acceptance: In rare cases the personnel were reluctant to use the solution. According to the the target companies, this was due to a lack of expertise or even a suspicion of being surveilled. Although the end-users were not highlighted in this paper due to its more organization-centric approach, it is worth noticing that a functional relationship between the organization and an IoT solution alone doesn't necessarily guarantee a successful adoption. As stated previously in this paper, we are already preparing a new article addressing the user-centric matters.

\section{Conclusions}

The experiments yielded promising results in the sense that most company representatives perceived an increase in their knowledge of the possible IoT solutions and their relevance to their business, as well as their company-specific solution feature and quality requirements. Quoting the majority of representatives, the reachable benefits became more clear during the experimentation through concrete deployment, giving further encouragement regarding the beneficiality of such experiments.

However, the system used in the pilots left a lot to wish for in terms of both hardware and software, as none of the experimenting companies could integrate the pilot system to their everyday processes without some level of quality improvements or customisations. The frequently observed inaccuracy issues and restricted battery life were deemed the most most significant hardware issues. In terms of software, and more specifically the user interface, the companies were hoping for a wider feature set, and especially the ability to investigate historical data in both numeric and graphical format. Additionally, the usability of the UI was found lacking.

Albeit limited in quantity, the target companies encountered a considerably homogeneous set of issues during the experimentations, suggesting that it might be possible to build a general list of requirements for an IoT monitoring device to be used in the SME setting. However, due to these challenges, estimating the overall costs and the return on investment was found difficult. Although this study provides fruitful foundations for further research, drawing further conclusions will require a considerably larger sample size.

\section{Limitations}

The results of this initial study are based on a limited number of experiments conducted with a specific Offthe shelf- solution, lacking several fundamental features, such as a clear visualisation of historical values. Thus, the generalizability of the results is low due to the dependency on one technology. Also, comparisons to other possible methods of acquiring 
first-hand knowledge were not possible during this study.

This study emphasizes the technical factors when analysing the suitability of specific IoT solutions. Hence, a more thorough review on IoT's suitability in specific business environments would require involving the organizational and personal factors [16], as well as taking a deeper look at the data accessibility [17], whose impact has been considered significant in previous IoT studies.

\section{Further research and recommendations}

The initial findings here suggest that there is potential in transforming various small and medium-sized businesses towards a more data-driven and automated approach in their routine activities by using different sensor solutions. Based on our findings and the feedback collected from the potential end-users, the factors presently limiting the use of low-cost, multipurpose IoT solutions are possible to identify and overcome. Once the technical issues are solved, the mechanisms of business transformation enabled by sensor solutions should be accessible for research. From this background, we propose an iterative approach towards further research on the challenge areas of multipurpose IoT solutions and their applicability in the SME context. More specifically, we suggest leveraging the findings presented in this paper to investigate their validity with other multipurpose IoT solutions and a larger target audience, and to refine our discoveries to achieve a deeper understanding on the SME-specific requirements for IoT solutions.

Piloting, even in a simplified form as presented here, is a powerful tool for discovering what is essential on deployment of new information systems. Based on our experiences it would be beneficial to 1) select the hardware so that the benefits of the IOT solution are actually achievable, even if this would require building tailored prototypes, 2) develop the interfaces for the users so that the required information is readily available, 3) do the testing/piloting in an iterative manner, collecting and analyzing data after each realized pilot test, taking into consideration even the organizational and knowledge-level related issues that will affect the outcomes.

\section{References}

[1] Williams, J. M., Khanna, R., Ruiz-Rosero, J. P., Pisharody, G., Qian, Y., Carlson, C. R., ... \& Ramirez-Gonzalez, G. (2017). Weaving the Wireless Web: Toward a Low-Power, Dense Wireless Sensor Network for the Industrial IoT. IEEE Microwave Magazine, 18(7), 40-63.
[2] Wortmann, F., \& Flüchter, K. (2015). Internet of things. Business \& Information Systems Engineering, 57(3), 221-224.

[3] Miorandi, D., Sicari, S., De Pellegrini, F., \& Chlamtac, I. (2012). Internet of things: Vision, applications and research challenges. Ad hoc networks, 10(7), 1497-1516.

[4] Lee, I., \& Lee, K. (2015). The Internet of Things (IoT): Applications, investments, and challenges for enterprises. Business Horizons, 58(4), 431-440.

[5] Swan, M. (2012). Sensor mania! the internet of things, wearable computing, objective metrics, and the quantified self 2.0. Journal of Sensor and Actuator Networks, 1(3), 217-253.

[6] Arendt, L. (2008). Barriers to ICT adoption in SMEs: how to bridge the digital divide?. Journal of Systems and Information Technology, 10(2), 93-108.

[7] Sheng, Z., Mahapatra, C., Zhu, C., \& Leung, V. C. (2015). Recent advances in industrial wireless sensor networks toward efficient management in IoT. IEEE access, 3, 622-637.

[8] Strong, D. M., \& Volkoff, O. (2010). Understanding Organization-Enterprise system fit: A path to theorizing the information technology artifact. MIS quarterly, 731-756.

[9] Venkatesh, V., \& Davis, F. D. (2000). A theoretical extension of the technology acceptance model: Four longitudinal field studies. Management science, 46(2), 186204.

[10] Delone, W. H., \& McLean, E. R. (2003). The DeLone and McLean model of information systems success: a ten-year update. Journal of management information systems, 19(4), 930.

[11] Seddon, P. B. (1997). A respecification and extension of the DeLone and McLean model of IS success. Information systems research, 8(3), 240-253.

[12] Corbin, J. M., \& Strauss, A. (1990). Grounded theory research: Procedures, canons, and evaluative criteria. Qualitative sociology, 13(1), 3-21.

[13] Davis, F. D., Bagozzi, R. P., \& Warshaw, P. R. (1989). User acceptance of computer technology: a comparison of two theoretical models. Management science, 35(8), 982-1003.

[14] Venkatesh, V., \& Davis, F. D. (2000). A theoretical extension of the technology acceptance model: Four longitudinal field studies. Management science, 46(2), 186-204.

[15] Gao, L., \& Bai, X. (2014). A unified perspective on the factors influencing consumer acceptance of internet of things technology. Asia Pacific Journal of Marketing and Logistics, 26(2), 211-231. 
[16] Kettunen, K., \& Salmela, E. (2017). Internet of Things as a Digital Transformation Driver in the Finnish Manufacturing Technology Industry. Journal of Innovation \& Business Best Practice Vol. 2017, Article ID 623981, 18 pages

[17] Wang, W., De, S., Toenjes, R., Reetz, E., \& Moessner, K. (2012, June). A comprehensive ontology for knowledge representation in the internet of things. In Trust, Security and Privacy in Computing and Communications (TrustCom), 2012

IEEE 11th International Conference on (pp. 1793-1798). IEEE. 